\title{
Marketing of Public and Business Affairs Subsystems of Socio-Economic Environment
}

\section{Summary}

The Romanian society is crossing one of the most important stages of its transition toward the integration in the European Union started with January 1st, 2007; this will define the final processes bound for the socio-economic reconstruction. Based on the previous experiences, an assumption rose up that, at this moment in the Romanian society there are two systems - business and public administration, placed on opposite, antagonistic, unfriendly sides. At the same time, there is the opinion that a proper public and private marketing could be the link between them. The link between these systems should make the relation useful to create and handle the cooperation and cooperation climate in these two environments.

The paper aims to present the systems, their characteristics, the opinion about the other, the identified link components, and to propose a solution for the link improvement. A small survey of the members' opinions, in both systems, will be the base of the analysis.

The first stage is to analyze each environment as an independent system: business system (BSy) and public administration system (PASy). We will present the structure, characteristics, interactions with other socio-economic components, etc.

The second stage will focus on the role of public and private marketing as tools of feedback reaction of the systems to the general environment dynamics. The marketing behavior is typical for the BSy and its level of marketing knowledge is higher than the poor level of marketing knowledge in PASy lacking the marketing attitude about public services.

* Prof. dr, National School of Political Studies and Public Administration, Bucharest, Romania. 
At the third stage shall be presented the conjunction between the two systems in a new structure „public and private partnership” and link between them through the marketing. This approach creates the possibility to use the marketing concepts, typical for BSy, in PASy as a natural component of the public-private partnership system.

\section{Introduction}

The necessity to change state structures has been pressing Romania all the time from 1989 until present. Its cause was the replacement of the socialist state system with the democratic state system and simultaneously the market economy replaced the centralized economy. The social and economic restructuring ere included a set of processes regarding legislation and regulation and also the changing of people conception.

There was a long transition time that was mainly focused on the legislation transposition. Starting from the objective of European integration and general compatibility of Romanian legislation with democratic states, it took place a large process of laws elaboration, approval and implementation in all the socioeconomic fields.

So, the business environment starts with law 31/1990 regarding the organization of commercial companies and they have now a complex system about company registration, accounting, taxation, customer protection and so on.

We could appreciate that the public sector was one of the last fields to benefit from its special regulation. It is relevant that the first law for public administration was issued in 1996 and only later other regulations were added.

The Romanian society is crossing one of the most important stages of its transition toward the integration in the European Union started with January $1^{\text {st }}, 2007$ this will define the final processes bound for the socio-economic reconstruction.

The democratic values include that the citizen has rights and obligations on one hand and on the other hand, the public administration has the role of serving citizen and to force them to fulfill the obligation or to punish them.

Based on the previous experiences, an assumption rose up that, at this moment in the Romanian society there are two systems - business and public administration, placed on an opposite, antagonistic, unfriendly sides. At the same time, there is the opinion that a proper public and private marketing could be the link between them. The link between these systems should make the relation useful to create and handle the cooperation and cooperation climate in these two environments. This is the reason that we should focus on the link between business and public administration by the marketing activity. 


\section{Starting point}

In order to have a better understanding of the images of business and public marketing activity, we made a small survey of the citizen opinions. The survey was made on a group of 139 subjects - 116 from business environment and 23 from public administration structures. The ratio does not respect the ratio between the number of employees in public and business sectors: we are much more interested in getting additional and relevant information from the public sector.

Briefly we present the questions and the answers process to some items relevant for this paper:

- Q14 - Do you think that the public sector and the public services should have marketing activities?

\section{Yes}

No

- Q16 - Public services promotion and public awareness about founds administration will:

a. Increase the taxpayers expectations;

b. Facilitate a better communication between the two sectors;

c. No effect;

d. Clarify the tax pay obligation;

e. Make the acquaintance of society benefits by taxes.

- Q17 - Marketing theory knowledge and practice on public administration and public services will:

a. Decrease bureaucracy;

b. Improve the services;

c. Improve the communication between public servant and taxpayer;

d. Increase the public servants responsibility;

e. Change attitude in both sectors.

- Q18 - Are the public servants qualified for „market economy” and „European public sector”?

Yes

No

- Q19 - Do you consider that marketing specialists in public sector are desired?

Yes No

\begin{tabular}{|c|c|c|c|c|c|c|c|}
\hline Question & Yes & No & a. & b. & c. & d. & e. \\
\hline Q14 & $\mathbf{9 3} \%$ & $7 \%$ & & & & & \\
\hline Q16 & & & $7 \%$ & $65 \%$ & $19 \%$ & $27 \%$ & $12 \%$ \\
\hline Q17 & & & $57 \%$ & $44 \%$ & $29 \%$ & $17 \%$ & $35 \%$ \\
\hline Q18 & $2 \%$ & $98 \%$ & & & & & \\
\hline Q19 & $92 \%$ & $8 \%$ & & & & & \\
\hline
\end{tabular}


The total answers to Q16 and 17 could exceed $100 \%$ because they were allowed to tick more then one answer.

As a result:

- $93 \%$ of subjects think that the public sector and the public services should have marketing activities;

- 98\% of subjects consider that public servants are NOT qualified for „market economy” and „European public sector”;

- $92 \%$ of subjects consider that marketing specialists in public sector are desired;

- $65 \%$ assess that public services promotion and public awareness about founds administration will facilitate a better communication between the two sectors;

- 57\% assess marketing theory knowledge and practice in public administration and public services will decrease bureaucracy; $44 \%$ assess they will improve the services and $35 \%$ expect they will change attitude in both sectors.

The survey confirms the empiric supposition that public sector lacks using marketing techniques and that they could be a link element between private and public environments.

\section{Systems presentation}

Business environment experiences a rapid development by the individual private initiative and later by the privatization program. The conception of the private entrepreneurs was adapted easier to the market economy expectations. This is because of certain factors as we mention:

- Certain entrepreneurships know, at least theoretically, the market economy requests;

- Foreign investors, experts of the occidental business environment appear;

- Private entrepreneurs have courage to start business and to adapt them and themselves to the international practices;

- Managers are acquainted with practical and then theoretical knowledge.

The public central and local administration environment has a naturally much slower changing process. The process of drawing up the legislation system, in conformity with the expectations of market economy states, was a complex, difficult and long term one.

From the human resources point of view, the two sectors offer different opportunities, so they were attractive for two segments of people with different characteristics.

The business environment was very attractive because of the company management's various methods of personnel motivation; the most important in our opinion are:

- High level of salaries (compared with public sector); 
- Professional satisfaction;

- Training and continuous learning for employees.

These factors attracted from the labor market to businesses the personnel with the highest level of skills and field education.

The central administration provided the business sector benefit by a special attention to the legislation requested to stabilize the environment. We could assess that in the last 15 years the business environment had more laws than anyone expected. Every 4 years, and some time sooner, the Romanian Government decided to „change the rule”. The well know examples are the foreign investment law that was changed at least every two years and ones twice in a year, and the privatization law that has the record of being changed three time in the same year.

Even if the environment has a lot of dysfunctions it should be know that it benefits from several facilities as well. There were, for example, a lot of programs that support small and medium enterprises (SME's) such as: marketing activities; training of personnel on business marketing and management; start up consultancy and start up investment.

The business system (BSy) can be presented, in our opinion as in Figure 1.

The public administration system (PASy) has not enjoyed too much attention during last 15 years. It is mainly based on the human resources. As a result, the administration is working with people for people and the important impact is through the public services. As we well know, the specificity of marketing approach to services is the personnel component.

The absence or weak usage of the personnel motivation components in the public sector has caused the personnel with old and obsolete practice to remain, and to attract young people with a low level of education or with no other options.

This relative polarization of personnel between the two sectors of activity generates the appearance of the theory of incompetence and bureaucracy related with the public sector and the arrogant and exaggerated aspirations in the private sector. The representation of the public administration system (PASy) could be as in Figure 2.
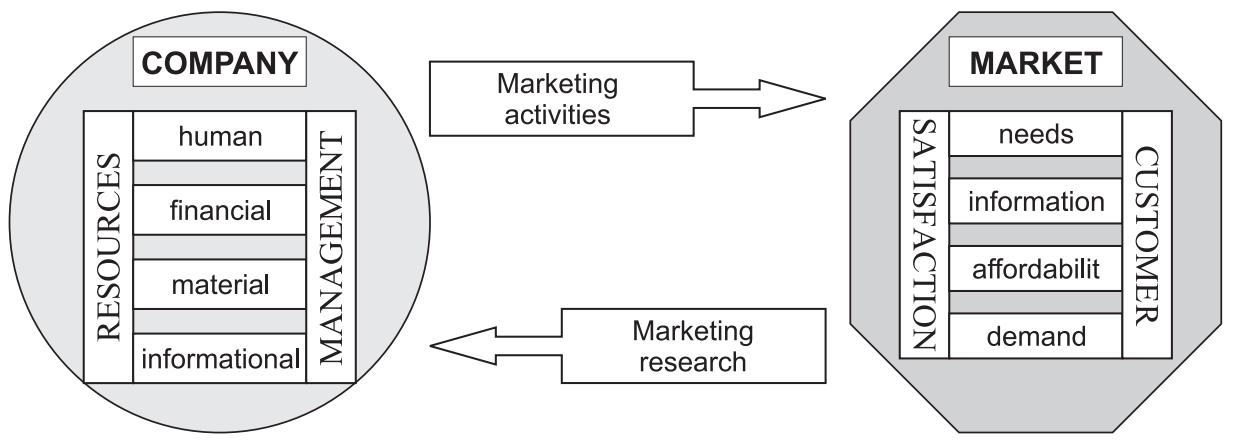

Figure 1. Business system (BSy) 

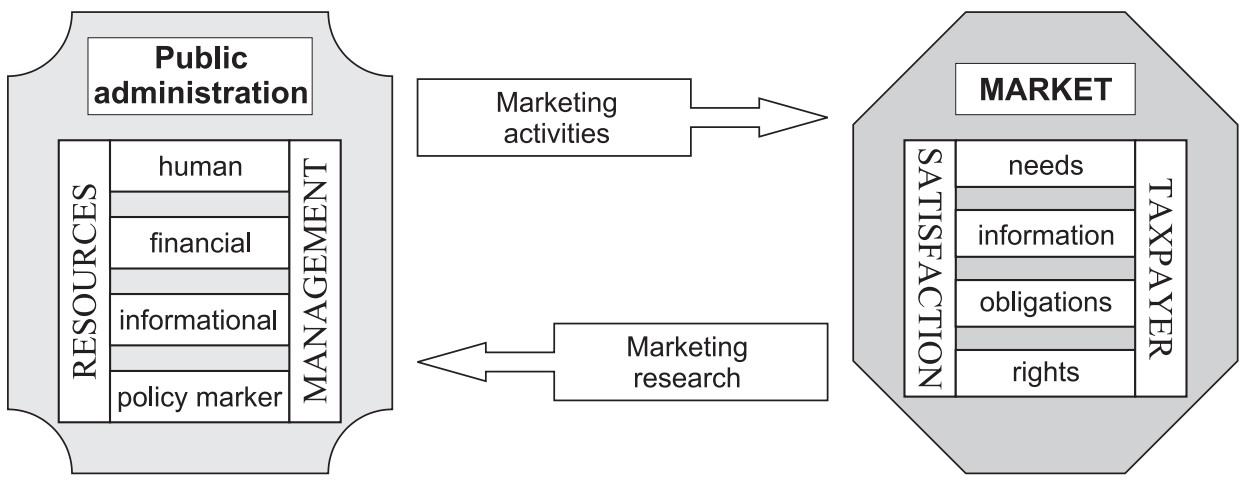

Figure 2. Public administration system (PASy)

Because of the personnel polarization, lack of resources, and lack of qualification in certain area such as marketing, at this moment, Romanian society has to deal with a weak cooperation between the public administration and business environment, with different forms of disagreement, some time even acute.

The difference in salary levels, in work conditions, in organizational and social culture, the lack of a civic self-awareness, and a weak communication make the disagreement stronger and form antagonistic groups, as well as the expression like „US-THEY”.

\section{Business and public marketing}

There is a unanimous vision, at the conception level, that the public-private partnership is necessary. There are efforts in this direction starting with the experience of other states from the European Union or other developed countries, already experienced and available to assist and support the local demarches in Romania.

So, the application of the marketing concepts for the public sector promotion could be a way for their beneficiaries, majority parts of the private sector, to know better the relationship aspect between the two sectors and the mutual dependence of them. If we redesign the structure with both actors at the same time, as they have to work in real life we can easily highlight the role of marketing.

The stronger marketing component with applicability in this process is "public awareness" referring to various projects in which the role of each citizen is very important. The absence of the funds needed for the implementation of different policies and the social objectives is determined by the fact that the population majority neither knew how to obtain public funds and nor how they are spent. What they are aware of is the direct contact allocation without bids, cor- 


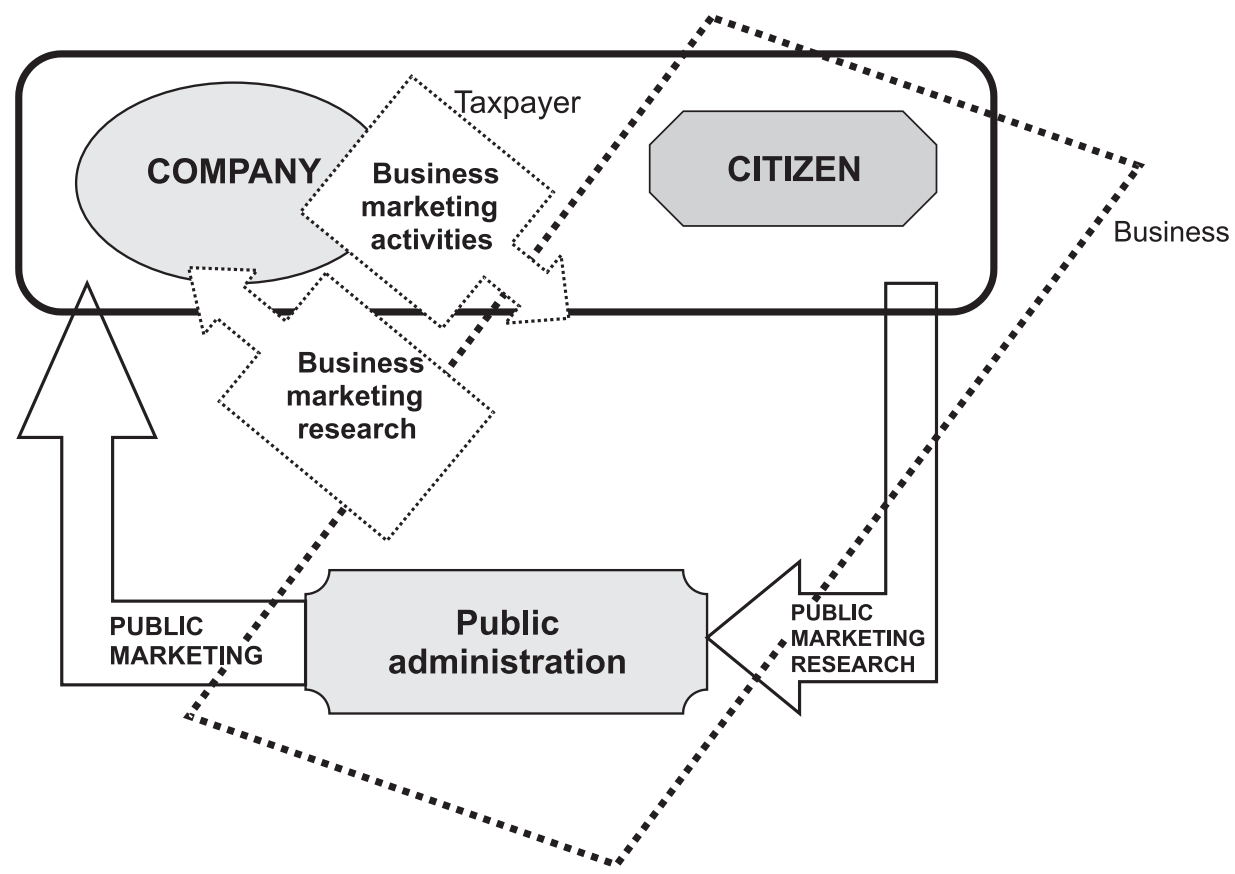

Figure 3. Business and public administration systems

ruption at all levels, lack of professionalism, bureaucracy: all of these generate a certain degree of mistrust to local and central authorities.

It is true that, at the same time the private sector has its share of contribution in this un-proper climate. For sure the corruption is increased by the continuous attempts to obtain facilities: penalties exoneration, shortening or prolonging of deadlines, unreal declarations, and so on, could be reasons of perpetuations of this situation and its development to large scale in public-private relationships.

It creates a spiral between the public and private environment supported by both sectors through the individual or group interests and it continues to generate an un-proper climate, which is reported to the whole society.

We consider that these structures could be consolidated by the marketing theory and the marketing activities aimed to highlight the role of these two components of general development of Romanian society, regional development, and economic development on the whole, or each company development, so together to better serve the population's economic and social needs.

Another form of the cohabitation between the two systems and their „socioeconomic system” is a form of „eco-system” as designed in Figure 4. This diagram shows that each component plays two roles depending on needs. The company offers/supplies the market for individual customer, for other companies and for 


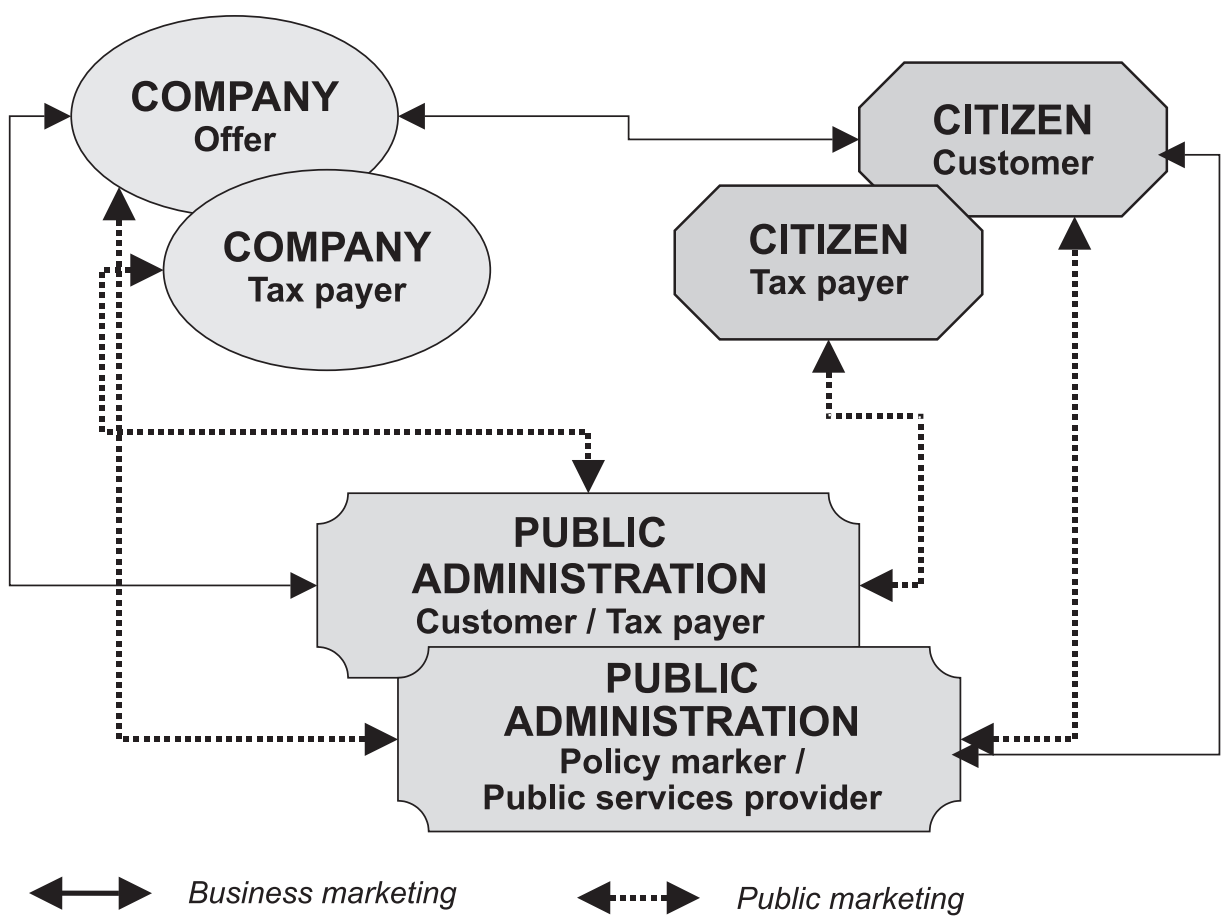

Figure 4. Business and public marketing

public administration. In this case the company is interested in marketing research to be any time in line with the market trends, the customer desire, demand and satisfaction. The marketing activities include the promotion of the company offers and marketing mix it designs for its target segments.

The public administration works as policy maker and public service supplier. It has to know the citizen expectation from the officials as national social policies in order to offer the motivation to pay taxes. The economic policies have effect on the companies as economic actors and influence the tax paid by them. On the other hand the public services has to be promoted to the citizens if they are free as a return for the already paid taxes and if they are charges to motivate a potential discrepancy between offer and customer satisfaction.

A start for redesigning the public-private relationships could be represented by the investment projects in infrastructure. They are, recently under regulation by the Government Ordinance no. 16/2002, Government Ordinance Emergency 15/2003 and Law 293/2003 that allowed the public-private partnership on the investment field.

These regulations have the reason to clarify the ways of designing, finance, construct, exploitation, service and transfer of any public assets according to the public-private partnership. 


\section{Marketing of public-private partnership - a potential link}

Public-private partnership is a method to introduce the private management in public services by the contractual links on long term bases between a private operator and a public authority. Public-private partnership assures the public service totally or partially, as a function of the private fund involved and asks for the private sector knowledge related to the efficient administration; thus, it offers of better quality public services. Using the marketing tools in promoting these services and supporting the way of offering them to high level of quality consolidates the link between public and private environment.

The public-private partnership, if defining start from the key words, includes:

- Partnership for action is formed by two or more partners joining to realize together an activity, an objective, a subject, a fact, an institution, a business. In the public-private partnership the main elements belong to the two sectors and have as aim the public interest objectives.

- Public presumes that it belongs to the collectivity or to the local, regional or national society. This determines the obligation for it all to be conducted based on specific laws and regulation and handled by central or local authorities.

- Private defines that it belong to the individual property, free initiative, market economy and it is controlled by demand and supply rule.

The public-private partnership represents the association between the two components aimed to achieve public interest objectives by joining characteristics and principles of business approach, able to increase efficiency and effectiveness. The partnership is the opposite of opposing, fight, aggressiveness, and it is based on understanding, cooperation between partners to achieve common objectives. The steps of building a public-private partnership are:

- Initiating project by the public authority's or by the private sector's initiative based on the society needs;

- Elaboration of „pre-feasibility” to offer information about the possibility and the effects of the objectives achievement;

- Publishing the advertisement related with the initiation of a public-private partnership for the project implementation and/or public debate;

- Issuing the „Letter of intent” regarding the involving in project implementation;

- Negotiations of the project implementation conditions with the selected investors;

- Concluding the "The project agreement" with the selected partners by the public authority in charge to handle the project;

- Elaboration by the public authority together with the partners from the private sector of „Project feasibility study”;

- Hierarchy of the investors' offers by the efficiency in technical-economic and financial index; 
- Negotiation of „Public-private partnership contract” with the investor placed first in the classification of the offers hierarchy, until the best results is obtained;

- Exploitation of the project results according with the „Public-private partnership contract" by the private partner;

- Transfer to the public authority of the public assets obtained by the project at the end of „Public-private partnership contract”.

The main types of investment project, that could by made by public-private partnership, are: Design-Build-Operate (DBO); Build-Operate-Renewal of Concession (BOR); Build-Operate-Transfer (BOT); Lease-Develop-Operate (LDO); Rehabilitate-Operate-Transfer (ROT); Build - Own - Operate - Transfer (BOOT).

- Public-private partnership is based on the next cooperation principles:

- Free competition in investor selection;

- Fixed set of criteria, easy to measure, transparent in investor evaluation;

- Confidentiality;

- Neutral and preventive about conflicts of interest;

- Following the schedule of the selection procedure and the project implementation;

- Clarity in communication;

- Honesty in project implementation and transfer;

- Fulfilling the accepted obligations.

The public-private partnership is also based on the relevance and viability criteria:

- Fulfilling the public interest needs, but under the administration of the private sector tools;

- Common objectives, evident and identifiable by both parts;

- Existence of the politic support for the project,

- Public fund availability and resources mobilization;

- Previsions/perspectives related to the added value and project efficiency;

- Existing interest from the private sector;

- Possibility of risks transfer to the private sector;

- Necessity of both sectors implication;

- Procedures/regulation of project implementation.

Project implementation by a public-private partnership assumes that, in the first step, the results exploitation will take place in the business administration system. As it could be seen from the steps of a public-private partnership building and then the business principles applied on the implementation and results exploitation, the business marketing should be present and its techniques successfully applied. Simultaneously should programs of public awareness be developed about the role of public administration in the partnership and the benefits of the local and national communities. 


\section{Project marketing a tool of business and public marketing}

According to the marketing principles, projects marketing take specific forms of the general functions as:

a) Market investigation, project needs. This function implementation has the role of obtaining information about the potential and existing markets, system of demands, local and international finance suppliers (grants), their motivation, customers behavior, competition, environment components related with the company and market relevance, national and international strategic objectives.

b) Company dynamic connection to the social-economic environment. This function reflects the new vision of marketing about the companyenvironment relation: based on the company activity it must be all time correlated with the environment demands. Execution of it includes the renewing and resources mobilization able to value the opportunities and also to influence the environment. The project management promotion makes possible the development in the complementary areas and focus on the objectives-results link.

c) Satisfying at high level of the environment demands. These could have different forms of expression: needs of consumption, structural and institutional change, information and socio-cultural needs. This function requests that the project implementation should lead to the expected result, that will get its material form in solution (projects) - projects documentation - in order to produce the expected change.

d) Maximizing the economic efficiency. This function has its role in resources mobilization, optimizing the structures according with the organization objectives for process to carry on by a motivational climate inside project constraints.

Complexity and projects market evolution, on the one hand, and projects ideas on the other hand, as well as the implied factors of attitude influence the environment. These include all actors and forces that influence the project marketing activity. Marketing environment has a fluid, dynamic character, reflecting opportunities and threats, restrictions with strong effects, as an open system.

According to the extreme complexity and the different ways of behavior, a clarification of environment elements is compulsory, and so it is the nature and the influence of them on the organization's marketing activity.

\section{Conclusions}

Public sector services promotion and the optimizing of its relation with its contributors could explain the rational ensemble that exists between the components and the system of mutual support. Public-services marketing rise up as a 
necessity and could use the business marketing tools, and evaluate simultaneously the politic marketing that has a faster and stronger development in Romania.

Using the marketing principles in public-private partnership and in exploitation of projects results in efficiency, effectiveness, and free competition principles, will lead to increased mutual reliance between the two sectors and to improved communication. At the same time it will lead to a proper transfer of knowledge from business to public environment and help realize the level of assumed risks that determine the difference between the levels of benefits.

Public sector marketing shows up as a necessity and it can use the tools of business marketing, offering add value to the politic marketing which knows a faster and stronger development.

Efficient communication establishment between the two environments will lead, for sure, to the development of a segment of satisfied citizens, employees, owner and vice-versa.

The research was extended to a bigger number of subjects, about 2000 and the results will offer a better understanding of the subject.

\section{References}

Andreasen A.R., Marketing Social Marketing in the Social Change Marketplace, "Journal of Public Policy \& Marketing”, Vol. 21, No. 1, 2002.

Bovaird T., Loeffler E., Public Management and Governance, book review.

Brown Ruby M., Marketing Public Sector Training: A Case Study of MIND (Management Institute for National Development), February 12, MIND Jamaica 2004.

Bruhn M., Marketing fur Nonprofit Organisationen, Kohlhammer, Germany 2005.

Buček M., Pauličková R., Use of Marketing Instruments in Development of Towns: Case Study Slovakia, University of Economics in Bratislava\& University of Ss. Cyril and Methodius in Trnava.

Florescu C., Marketing, Editura Marketer, Bucharest 1992.

Grigorescu A., Project Management, Editura Politeia-SNSPA, Bucharest 2005.

Grigorescu A., Bob C., Dobrescu E., Guide of Public and Private Marketing, Editura Uranus, Bucharest 2006.

Lovelock C., Wirtz J., Services Marketing, Prentice Hall, UK 2006.

Matei L., Public services, Editura Economica, Bucharest 2004.

Polonsky M.J., Binney W., Hall J., Developing better public policy to motivate responsible enviormental behaviour, "Journal of Nonprofit and Public Sector Marketing, Vol. 12, No 1, 2004.

“Journal of Nonprofit \& Public Sector Marketing”, Vol. 12, No. 1, 2004, http://www.Haworth Press.com;

Canada. 2003. La recherche sur l'opinion publique au gouvernement du Canada. http://www. communication.gc.ca/reports_rapports/por_rop/rop_rapport_annuel2002-2003.

Government Ordinance no. 16/2002.

Government Ordinance Emergency 15/2003.

Law 293/2003. 


\section{Marketing podsystemów publiczno-społecznego i biznesowego w otoczeniu ekonomiczno-spotecznym}

\section{Streszczenie}

Społeczeństwo rumuńskie, od momentu wejścia tego kraju w styczniu 2007 r. w struktury Unii Europejskiej, realizuje procesy restrukturyzacji systemu społeczno-ekonomicznego. W społeczeństwie rumuńskim funkcjonuje przekonanie, iz dwa podsystemy: publiczno-społeczny $i$ biznesowy sq nastawione antagonistycznie wobec siebie, znajduja sie po przeciwnych stronach systemu ekonomicznego. Równocześnie powstało przekonanie, że narzędzia marketingu mogtyby potaczyć te dwa podsystemy. Zwiqzek między tymi systemami powinien stworzyć klimat wspótpracy tych dwóch podsystemów funkcjonujacych w otoczeniu społeczno-ekonomicznym.

Artykut analizuje podsystem biznesowy (ang. business system BS) i publiczny system administracyjny (ang. public administrative system PAS). Przedstawia ich strukturę, cechy oraz formy wspótdziałania z innymi elementami sktadowymi systemu społeczno-ekonomicznego. W końcu zaprezentowane sq możliwości wdrażania instrumentów marketingu w celu powiqzania ze sobq podsystemu biznesowego i publiczno-spotecznego. 